How to cite this article:

Musa, U. F., \& Suleiman, I. (2020). Exploring the strategies for building resilience to poverty in Bauchi State, Nigeria. Journal of International Studies, 16, 145-158. https://doi.org/10.32890/jis2020.16.9

\title{
Exploring the Strategies for Building Resilience to Poverty in Bauchi State, Nigeria.
}

\author{
${ }^{1}$ Umar Farouk Musa \& Ibrahim Suleiman \\ Department of Political Science, \\ Faculty of Social and Management Sciences, \\ Bauchi State University, Gadau, Nigeria. \\ ${ }^{1}$ Corresponding author: umarfmusa@basug.edu.ng
}

\begin{abstract}
The challenges of poverty and insurgency have caused problems of different dimensions in north-eastern Nigeria. Specifically, the Bauchi state had recorded 89.5 percent of Multidimensional Poverty Indicators, more than any other state in the country. The main objective of this study is to explore the strategies that could build resilience to poverty in the study area. To achieve this, a qualitative research design, via semi-structured interview and purposive sampling, were applied. Accordingly, twenty-two informants from the ministries, agencies and commissions, in addition to some selected underprivileged people, were consulted during the data collection. Consequently, the findings from the study indicate that national, state, community and individual strategies were suggested to overcome poverty and other socioeconomic challenges that are faced by the people in Northeastern Nigeria in general, and Bauchi state in particular. The views of the informants ensured that the necessary measures can be taken to address the socioeconomic challenges identified in the state. Some of the community strategies include security initiatives, collaborations with NGOs to cushion the effects of poverty in the towns and villages, and the contributions from religious and traditional institutions. Furthermore, personal empowerment, enhancing peoples' confidence, and skills were identified as the individual strategies. Subsequently, by strengthening the federal government, states as well as security arrangements could avert the problems discovered. The expansion of poverty reduction programs, accessible educational policies, youth empowerment schemes, rehabilitation, reconstruction, and the overall development of northeastern Nigeria were suggested.
\end{abstract}

Keyword: Poverty Reduction, strategies, building resilient, Bauchi State. 


\section{Background to the Study}

Poverty is a socioeconomic problem that has impacted humanity in most developing nations. Nwabughiogu (2015) stated that, based on statistics, more than 110 million Nigerians faces the perils of poverty, despite the various policies and programs that have been implemented such as Operation Feed the Nation; National Poverty Eradication Programme and the current N-Power, among others. Alkire, Roche, Seth, and Summer (2015) had suggested that the manifestation of poverty in Nigeria and Bauchi state in particular, is at 89.5 percent, higher than the other states in the country. At the same time, the effects of insurgency in the northeast region, specifically insecurity and deprivation to daily businesses, has affected the people. Therefore, the northeastern region is most affected by the insurgency, while the relative poverty figure is at 77.7 percent. Furthermore, illiteracy and unemployment were the fortuitous opportunities used in recruiting the futile youth into these rebellion activities (the kidnnappings and bombings by the Boko Haram insurgents), thereby destroying lives and properties of the people in the northeastern Nigeria (Salisu, Afandi \& Yusuf, 2015 \& Ojo, 2013).

A windstorm that occured on 22nd May, 2018 in Bauchi state had affected many of the poorest people in the region. This had caused an increase in hardship faced by the people to acquire basic amenities. Moreover, the disaster had caused a lot of damages to human lives, houses, public buildings, and had subjected the people to hardships. Consequently, the need to carry out this study became imperative in order to explore the processes of building resilience and the strategies to cope with the aforementioned misfortune in the study area. Accordingly, this study is structured into integral parts, as follows: the introduction; research questions and objectives; method of data collection; the review of related literature; discussions; recommendations; and conclusion.

\section{Research Objectives and Questions}

This study aims to achieve its objectives, and answer the research questions: To explore the ways to reduce poverty in the study area and to establish the strategies to build resilience to poverty in Bauchi state; i) What are the ways to reduce poverty in study area? ii) What are the strategies to build resilience to poverty in Bauchi state?

\section{Literature Review}

This section of the study highlights the reviewed literature on the related topic. The concept of poverty is generic, and connotes the absence and insufficiency of basic needs. To further support these assertions, the World Bank (1999) defined poverty as 'hunger, insufficient shelter, inability to attain and go to school, unawareness, poor portable drinking water, unsecured future, fear, inadequate freedom and representation, as well as powerlessness' (Foli \& Béland, 2014). Furthermore, the trend of poverty is comprised of denial to medical services, uncertainty, illiteracy and low income, respectively. 
Hussaini (2014) suggested that poverty is the incapability to attain political, social, economic, and psychological wellbeing. The political manifestation of poverty entails the lack of power, exclusion from decision making, denial of natural rights as well as depleted political participation. Social assessment of poverty refers to low self-esteem, feelings of mediocrity, isolation, recognition, and debility (Jerome, 2011). In addtion, Idris and Kabiru (2019) have asserted that poverty is also synonymous to the absence of basic health care, education, poor access to roads and portable drinking water, amongs others.

The term resilience is derived from the Latin word 'resilience', which means to recover, rebound or start (Fan, Pandya-Lorch, Yosef, Fritschel, \& Zseleczky, 2014a). Resilience gained recognition from the works of Holing in 1960, whereby resilience was a concept used in the study of ecosystems and social sciences. Therefore, by the 1970s, the concept of resilience had become synonymous to development, and is currently used in poverty research and coping strategies. Subsequently, the concept of resilience drew the attention of many development experts as it provided a new paradigm which could be employed to efficiently plan and appraised shocks as well as stress that intimidated the welfare of vulnerable populations (Folke, 2006). Therefore, resilience is the capability of a social system and its components to absorb; anticipate and accommodate; or regain from the impact of dangerous occurrences in a timely and efficient manner (Bahadur, Ibrahim, \& Tanner, 2010).

Current literature have indicated that over twenty years ago, the application of resilience was a multifaceted construct that changes within the context of cultural background, age, time, and based on individuals who experienced life adversities (Prasad et al., 2009). The resilience system is characterized by various activities such as policymaking process, economic transformation, partnership within the community, resources conservation, and other activities and measures that are established for economic recovery. It also covers effective management of governmental institutions, capability of enhancing decentralization, community involvement, flexibility in public affairs, and the policymakers' decisions within the local communities (Connor \& Davidson, 2003).

Resilience is a multidimensional concept that can be applied to the study of social, political, economic, ecology or environment, psychology, engineering, and health. Subsequently, it was found that the concept of resilience can also be applied by the humanitarian workers and other nongovernmental organizations to alleviate the effects of poverty, as well as other humanitarian discomfort (Barua, Katyaini, Mili, \& Gooch, 2014; Breisinger, Ecker, Maystadt, Trinh Tan, et al., 2014; Fan, Pandya-Lorch, Yosef, Fritschel, \& Zseleczky, 2014b).

Duncan, Tompkins, Dash, and Tripathy (2017) had studied the relationship between the rice farmers' resilience to the hazards in Mahanadi Delta, India by using the mixed method; household survey, semi-structured interviews and focus group discussions. The study investigated the resilience of the household livelihood strategies, cropping practices, land ownership, climate hazard impacts, access to institutional support and coping, and adaptive 
strategies. Descriptive statistics and random effects models correlation were applied in the data analysis.

The findings from the study in India had indicated that most of the rice farmers were predominantly subsistence, hence, they experienced approximately fifty percent of the damages due to flood and hazards from climatic change. The farmers undertook coping strategies to sustain their lives. Furthermore, the results highlighted the institutional challenges such as land ownership, inadequate formal institutional support, and other culture-related activities, namely too much spending on weeding that had subsequently depleted their resources. However, the study was limited to rice farmers. To better understand the concept of resiliency, it would require multidimensional approaches to enable all categorize of farmers to cope with various difficulties associated with farming.

A study on the resilience to consumption practices during crises in Germany with 14 in-depth experts' interview and 27 biological households from different welfare and charity organizations was carried out. The data collected had facilitated the analysis of everyday consumption habits that help people undergoing economic hardship to cope. The study asserted that economic hardship is a worldwide phenomenon, beyond unemployment. It encompasses poverty, illness, low skills, migration, and displacement (refugee). The results indicated that two major coping strategies were employed by the informants, which are; controlling and reduction in consumption, and subsistence production for self-consumption. These strategies were also employed in the production of goods and services such as planting, harvesting fruits, and other vegetables. The strategies were highlighted as a viable coping strategy. Furthermore, the informants narrated that farming and crafting should be encouraged during economic hardship. Moreover, the lack of mobility was considered one of the main reasons for poor access to food and natural resources. The study suggested a welfare state system of government (Reeskens \& Vandecasteele, 2017). Nevertheless, the aforementioned study was carried out in a developed economy, with a limited numbers of household.

Muhammad, Nazariah and Isah (2018) suggested that poverty, elite's manipulation, political instability, poor governance, social inequality, poor civic-education and monetization of politics were identified as the 'push' factors in Nigeria. These factors would later influence the affairs of the federal republic of Nigeria that would lead to many complications in the future. The study further acknowledged issues such as the access to power, regionalism, socio-societal influence, high living standard and ethno-religious sentiments, which were referred to as 'pull' factors. The politicians had purposefully induced poverty within the society via ineffective policies, social disillusion and loss of confidence in the state authorities. Similarly, individuals with low status and class were denied the opportunities to participate in politics and economic activities in the country. These factors contributed to the current predicaments faced by the federal republic of Nigeria. The need to carry out this study in a developing economy is desirable. Alkire, et al, (2015) indicated that the multidimensional poverty index for the Bauchi state is at 89.5 percent. Therefore, the Bauchi state was chosen for this study due to its highest poverty rating within the country that necessitated further examination. 


\section{Method of Data Collection}

This study applied a qualitative research approach and collected data through a semi-structured interview technique. Thereafter, twenty-two informants were consulted from ministries, agencies, and commissions in Bauchi state, particularly from the Ministries of Cooperatives and Poverty Alleviation; the Bauchi State Commission for Women and Youth Rehabilitation Agency and The Ministries of Social Welfare and Community Development on the 20th August, 2017. The population of the study consisted of government officials, stakeholders, participants, and other beneficiaries of the Bauchi state poverty reduction programs, as well as other underprivileged people through the purposive sampling design.

The informants were selected based on the convenience of access, proximity, and suitability (Palinkas et al., 2013). The data was analyzed through discussion analysis, while the Nvivo version 11 software was used to facilitate the presentation of the results. The organization, categorization and articulation of the data was carried out prior to the analysis of the data collection. The findings were then presented and discussed.

\section{Results}

This section of the study presents the results obtained from the viewpoints of twenty-two informants on the strategies to build resilience to poverty in the Bauchi state.

\section{Profile of the Informants}

The twenty-two informants were comprised of people from the Ministry of Cooperatives and Poverty Alleviation, Ministry of Social Welfare and Community Development, Bauchi State Agency for Youth and Women's Development and State Agency for people with disabilities. Others include farmers, poor villagers and small-scale business operators. Table 1 presents the general profiles of the informants.

Table 1

Profiles of the Informants

\begin{tabular}{ccccccc}
\hline S/N & Informant & Gender & Age & $\begin{array}{c}\text { Marital } \\
\text { Status }\end{array}$ & $\begin{array}{c}\text { Educational } \\
\text { Qualification }\end{array}$ & $\begin{array}{c}\text { Working } \\
\text { Experience }\end{array}$ \\
\hline 1 & A1 & Male & 55 Years & Married & Master's Degree & 34 Years \\
2 & B1 & Male & 47 Years & Married & Master's Degree & 30 Years \\
3 & B2 & Male & 45 Years & Married & First Degree & 26 Years \\
4 & B3 & Male & 46 Years & Married & First Degree & 25 Years \\
5 & B4 & Male & 43 Years & Married & First Degree & 23 Years \\
\hline
\end{tabular}

(continued) 


\begin{tabular}{|c|c|c|c|c|c|c|}
\hline $\mathrm{S} / \mathrm{N}$ & Informant & Gender & Age & $\begin{array}{l}\text { Marital } \\
\text { Status }\end{array}$ & $\begin{array}{c}\text { Educational } \\
\text { Qualification }\end{array}$ & $\begin{array}{l}\text { Working } \\
\text { Experience }\end{array}$ \\
\hline 6 & B5 & Female & 43 Years & Married & First Degree & 22 Years \\
\hline 7 & B6 & Male & 44 Years & Married & First Degree & 23 Years \\
\hline 8 & B7 & Male & 43 Years & Married & First Degree & 21 Years \\
\hline 9 & B8 & Male & 42 Years & Married & First Degree & 30 Years \\
\hline 10 & B9 & Male & 45 Years & Married & First Degree & 22Years \\
\hline 11 & $\mathrm{C} 1$ & Female & 44 Years & Married & First Degree & 15 Years \\
\hline 12 & $\mathrm{C} 2$ & Male & 43 Years & Single & First Degree & 13 Years \\
\hline 13 & $\mathrm{C} 3$ & Male & 35 Years & Married & Diploma & 12 Years \\
\hline 14 & D1 & Male & 36 Years & Married & Diploma & 3 Years \\
\hline 15 & D2 & Male & 26 Years & Single & Secondary & None \\
\hline 16 & D3 & Male & 30 Years & Married & Diploma & 5 years \\
\hline 17 & D4 & Male & 33 Years & Married & Primary & 6 Years \\
\hline 18 & D5 & Male & 40 Years & Married & Secondary & 5 Years \\
\hline 19 & D6 & Male & 34 Years & Married & Diploma & 5 Years \\
\hline 20 & D7 & Male & 35 Years & Married & Primary & 7 Years \\
\hline 21 & D8 & Male & 44 Years & Married & Secondary & 15 Years \\
\hline 22 & D9 & Male & 50 Years & Married & Diploma & 30 Years \\
\hline
\end{tabular}

The distribution of the informants are categorized into A1, permanent secretary, B1-B9 Directors, C1-C3 other staff below the rank of Director, and D1 and D2. Similarly, D3 to D9 include farmers, the poor villagers and small-scale business operators.

The concept of resilience refers to the ability to be courageous, strong, and to bounce back. The concept gained recognition in the field of development that emphazised coping mechanisms for stress, shocks, and misadventure on the poor and vulnerable. The results were also presented in figurative form for easy understanding. Accordingly, the perceptions of the informants were put together into individual, national, state and community strategies that have been suggested to overcome poverty and other socioeconomic challenges that are faced by the people in Northeastern Nigeria, and Bauchi state in particular.

Resilience appears to be an important framework that recognizes skills, attitudes, and abilities which empowers people to effectively discuss life's trials and promote economic development. It should be noted that resilient people have value orientation to make decisions that strike a balance between what is right and wrong. Other attributes of resiliency include the creativity to face life challenges, humor, initiatives, and proactiveness to improve their living conditions (Hurtes \& Allen, 2001). Individual resilience was adopted by this study to examine the individual farmers, businessmen, and the poor on their ability to cope with the effects of socio-economic hardships, apolitical, and policy failures in the study area. Similarly, the demographic and climatic issues, insecurity, and ethnoreligious problems had subsequently manifested into multidimensional poverty that have affected 
the northeastern Nigeria and Bauchi state. For instance, the activities of insurgents caused severe consequences on security, survival, employment, and had rendered many people homeless.

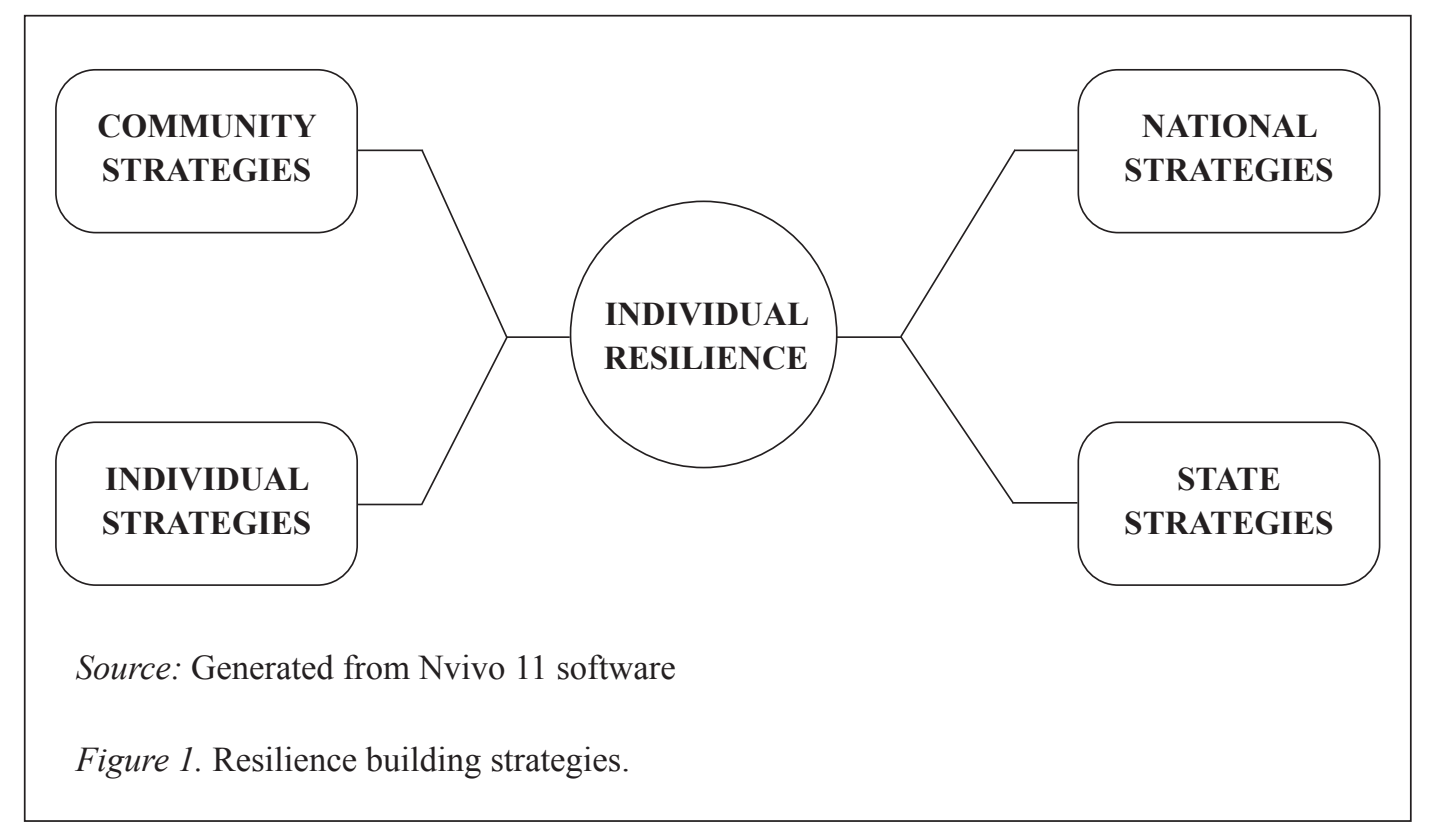

This section of the study was focused on the processes of establishing coping strategies to address the challenges identified that had induced poverty, according to the views of the informants. Literature further indicates that insecurity in Nigeria had affected the political, social, economic, and cultural aspects of life. These difficulties were caused by porous borders, the illegal proliferation of armed groups, militancy, unemployment, poor leadership and marginalization, and other social challenges (Obi, 2015). Therefore, the informants opined that the national, state and communities should complement the individuals to address the issue of poverty.

\section{The Individual Strategies}

Past literature have suggested the need for personal empowerment through the enhancement of peoples' confidence and skills to overcome economic constraints in the effort to support the underprivileged. This is comprised of support for individuals and interest groups to establish strategies that could improve the existing sources of revenue generation (Krantz, 2001). Additionally, human capital has contributed significantly to wealth creation, creativity, and poverty reduction. The informants had mentioned that; "I am of the view that individuals should strive hard and initiate self-employment strategies through business, farming and avoid reliance on job opportunities from the government. These will serve as ways to cope with the economic hardship and become productive to the society", (Informant XI). 
Furthermore, personal attributes and industrious personality were also suggested, for instance; "The strategies I suggested to the youth and the people is to embrace qualities such as dedication, hardworking and avoid laziness. They should think of small-scale business, farming, and learning some handwork to earn a living”, (Informant XVIII).

Other than that, informant X stressed on the need for self-security; "The best way to cope with these security issues is to devise measures on the intensification of self-security, employment of vigilante operators and community policing."

Attitudinal changes will lead to poverty reduction, by embracing different vocations and occupations. People would need to initiate any lawful opportunity to earn a living, even if it's selling firewood or charcoal, or washing clothes to survive. Our attitudes toward small scale businesses and other crafts should be improved (Informant XIX).

Another informant stated as follows:

"I am also of the view that individuals should strive hard to meet their basic needs in the facet of foods, clothes and shelter. Hard working is a basic approach to poverty reduction" (Informant XXII).

\section{The Community Strategies}

This study suggests that community strategies, in this context, refers to application of security initiatives that have been established to cushion the effects of insurgency and poverty via the towns, villages, religious and traditional leaders. Twigg and Calderone (2019) asserted that community resilience consisted of nine fundamental elements, namely networks and relationships, local knowledge, health, governance, communication, leadership, economic investment, resources, preparedness, and mental viewpoint.

Accordingly, the informants also opined that; "the establishment of community police, vigilance and support from the government and NGOs as well as the application of economic measures, specifically, job creation and redistribution of resources to the people", (Informant VII). Thus, the government, community leaders, and NGOs are expected to collaborate in establishing economic policies for the benefit of the poor, underemployed, destitute, and the unemployed.

The notion of community strategies as stated above are deemed imporant, and the people should be watchful against any breach of law. Moreover, informant V stated that; "I realized that government alone may not overcome the socioeconomic situation, so the government, private organizations, and individuals should work hand in hand to offer collaborative roles to achieve our goals; economic growth and development", (Informant IX). Based on the above views, this study highlights that the government alone may not proffer permanent 
solutions to the poor. Therefore, it is vital to establish collective actions with corporate bodies to ensure more efficient and permanent solutions could be attained. Informant IV has stated that;

\begin{abstract}
"Religiously, we need prayers and invocation so that God will give protection, relief, and bring the calamity to an end. Supportive activities at the local government, community level, and religious body should be emphasized. Exchanges of ideas through enlightenment campaigns, dialogue, and use of mass media will also mitigate these unforeseen circumstances", (Informant IV).
\end{abstract}

The suggestion for devotion is an essential aspect of life, as (Allah) answers all prayers of individuals and the entire state. The invocation is a noble technique for relief in Islam. Hence, based on the viewpoints of the informants, this study deduced that individuals should adopt resiliency to reduce the effects of poverty in the state.

\title{
The State Strategies
}

State strategies are the approaches and measures that have been suggested to the Bauchi state government to tackle the different socioeconomic challenges that occurred due to insurgency and poverty. For instance, as stated by one of the informants; "The Bauchi state government should establish agencies to relieve the victims of insurgency and increase yearly budgetary allocations and intensified efforts to repel the effects of the insecurity", (Informant III). Furthermore, "the provisions of capital in the form of soft loans to enable the poor and unemployed youth to set up their business. These will reduce joblessness and provide empolyment to the youth indulging in insurgency under control", (Informant XII).

It is proposed that the government felt that the best approaches among other measures were to provide relief materials to the victims, through the relevant ministries and agencies such as Bauchi State Agency for Youth Women Rehabilitation and Development (BACYWORD). In his presumption, informant $\mathrm{X}$ had proclaimed that; "The state government should encourage security agents to do their work without apathy, additionally, they needed reinforcements and equipment. The religious groups should embark on enlightenment campaigns at the mosque, church, and other public gatherings". Furthermore, as security agencies carry out their mandate and responsibilities, religious bodies should equally advocate for peace and tranquility. These approaches are considered appropriate. In the past, it was observed that the religious bodies and faith-based organizations had played an important role for conflict management through peace-building and conflict resolutions in Nigeria, Cambodia, and Mozambique (Haynes, 2009).

Consequently, the need for government to intensify security consciousness and training were the suggestions articulated by informant VIII, whereby the informant stated that; 
"Government should give protection, employment, capacity building to the destitute in the community". To reinforce employment, training and skills acquisition, Informant XIII inferred that; "The best ways to deal with the issue of insecurity are vibrant policy approaches on poverty reduction, youth empowerment, counseling on the value of hard-working. The youth should also be given practical training on different crafts such as electrical maintenance, carpentry, and plumbing for self- reliance". The state government should emphasize empowerment, since most of the security threats were attributed to idleness and underemployment. Therefore, the establishment of additional empowerment schemes will curtail these predicaments.

\section{The National Strategies}

The national strategies are the measures that have been suggested by the informants to the Nigerian government to reduce poverty, in relation to the insecurity situation that has affected the northern region, and Bauchi state in particular. With regards to this, informants one, three and four had articulated their views as follows:

"These security challenges had connotations to youth idleness, unemployment, therefore the best way to tackle is that the government, NGOs, and all stakeholders should establish employment generation policies that will provide additional job opportunities through reviving agricultural programs, capacity building, and entrepreneurship education", (Informant I).

Therefore, the government is expected to provide better employment opportunities to engage the youth and avert them from these illicit behaviors. Informant III, emphasized that:

"Poverty, ignorance, and unemployment are the major problems about the causes of the insurgency in northeastern Nigeria. Therefore, employment generation, commitment to educational development, awareness, and mobilization of resources to tackle these shall help individuals to cope with these challenges".

The need for the development of education was highlighted, as illiteracy was considered among the major causes of insurgency in north-eastern Nigeria and the study area. To emphasize the above arguments, the need for the mobilization of resources to manage the situation became necessary. Alternatively, informant IX postulated as follows:

"There are many ways to cope with these hardships; to me, the government should devise peace and conflict resolution at the regional level, establishment of industries, especially agro-industry to create new job opportunities for the teeming unemployed people. I think the establishment of community policing, cooperative societies for capacity building in different crafts will also yield better results". 
Therefore, peacebuilding efforts and conflict resolutions were deduced to be the best alternatives for internal security threats, especially for insurgency-related threats on religion, socioeconomic, and local politics. Various literature have suggested that dialogue is an effective medium for conflict resolution, particularly if the religious peacebuilding process is applied (Danfulani \& Fwatshak, 2002; Haynes, 2009).

\section{Discussion}

Attempts were made to discuss the results, validate previous studies, answer the stated research questions, and achieve the research objectives. The questions include: what are the ways to reduce poverty and the strategies to build resilience in the study area? The informants articulated four main approaches to address insurgency and build resilience to poverty. The proposed approaches consist of individual, community, state, and national strategies, respectively. For instance, the informants stated that physical qualities such as hard work and self-employment strategies such business initiatives, farming, and to avoid total reliance on government jobs, would serve as a strategy that could emancipate the individuals to cope with the economic hardship and become productive to the society. In support of the individual resilience strategies, prior studies have indicated that resiliency is the capacity to adapt and became flexible in the face of multiple challenges. Consequently, psychological resilience refers to the individual's ability to bounce back from stressful realities, quickly and efficiently. Similarly, resilient people have personal competence, and as well as the capacity to overcome negative emotions, thoughts and exhibit optimism in all situations (Sabina \& Ilyas, 2017). The findings from this study indicates that individuals should engage in business, farming and personal security arrangements to cope in all situations.

Furthermore, existing literature identified five basic characteristics that are associated with individual resiliency, namely positive coping or active problem-solving ability; positive effect, optimism; positive thinking or changing one's perception to a problem; realism approach i.e. Having realistic expectations and acceptance to difficult situations, and exhibit behavioral control through regulating individual emotional response (Douglas \& Amy, 2017). These characteristics are in line with the results of this study, in relation to the initiatives for business, hard work, dedication and perseverance.

With regards to the community strategies to overcome the insurgency and poverty holistically, the informants stated that "The establishment of community police, vigilante and support from the government and NGOs as well as the application of far-reaching economic measures, specifically, job creation and redistribution of resources to the people". Accordingly, the informants had proposed for the incorporation of security initiatives through religious and traditional institutions. These should cover the towns and villages across the state. The government, community leaders, and NGOs should come together and collaborate when establishing economic policies for the benefit of the poor, unemployed, and the destitute. 
Preceding studies have indicated that grassroots participation in community development was categorized into attending meetings, deliberations on matters relating to policy design, implementation and monitoring, and contributing financial resources and labor. It also included seeking new knowledge, information, and sharing experiences with other members of the community. Communities have also established rules and regulations, and have adopted technological innovations and project initiatives for the betterment of the people. Furthermore, issues relating to physical infrastructure such as roads, modern markets, and drainages among others were some of the community initiatives that were carried out in Nigeria. Social development programs such as town halls, libraries, and rehabilitation centers were also implemented. Others include health programs, educational, environmental, human, economic, water supply, community security and conflict resolution were some of the measures included within the dimensions of community initiatives (Adekeye \& Bello, 2013; Anyanwu, 1991; Community Development Agency, 2007; Abiona, 2009). These further validated the findings of this study.

This study highlighted the national strategies and concurred that the different poverty reduction programs earlier established by the federal government of Nigeria, particularly the Free and Compulsory Primary Education (PCPE); National Poverty Eradication Program (NAPEP); Operation Feed the Nation (OFN); Rural Electrification Scheme (RES); Rural Banking Program (RBP); National Directorate of Employment (NDE); Directorate for Food, Roads and Rural Infrastructure (DFFRI); Better Life Program (BLP); People`s Bank of Nigeria (PBN); (Musa, Abdullah \& Wahid, 2016). Family Support Program (FSP); Community Banks Program (CBP) and the Family Economic Advancement Program (FEAP) and Strategic Grains Reserves Program (SGRP); the Small and Medium Scale Enterprises Development Agency, (SMEDAN); National Directorate of Employment (NDE); National Poverty Eradication Program NAPEP; Microfinance institution (MFIS), among others were aimed at alleviating poverty in the country. Moreover, the state strategies included national programs with offices in Bauchi state, and other commissions and agencies to strengthen the individuals and communities. These were in line with the opinions of the informants, and proffer solutions to the problems addressed by this study.

\section{Conclusion and Recommendation}

The main objective of this study is to explore the strategies for resilience, amid poverty and insecurity that is currently being faced by the people in the Bauchi state, and the Northeastern Nigeria at large. The findings from this study indicated that individual, community, state and national strategies were the core perceptions of twenty-two informants. Moreover, the findings of this study provide insight to policy makers and others on the challenges that needs to be addressed in the north eastern Nigeria, and ensure the building resilience among its people hereafter. This study was limited to the Bauchi state, and had applied the qualitative research approach. 
It is proposed that future study should apply a survey design, via questionnaires. The following recommendations should be taken into consideration to alleviate the issues faced by the less privileged. Firstly, the expansion of poverty reduction measures across the rural, semi-urban and urban areas via agribusiness practices should be carried out since the study area has the potential for agriculture expansion and others natural economic activities. Secondly, accessible educational policies through funding, expansion and establishment of additional vocational schools could be implemented via public-private partnerships. Thirdly, youth empowerment schemes to carry out the rehabilitation, reconstruction and the overall development of the programmes in northeastern Nigeria. These scheme should include capacity building for the youths and provide soft-loans for individuals to set up their businesses.

\section{Acknowledgement}

This research has not received any specific grant from any funding agency.

\section{References}

Adekeye, A., \& Bello, W. N. (2013). Grassroots participation in decision-making process and development programmes as correlate of sustainability of community development programmes in Nigeria. Journal of Sustainable Development, 6(3), 47-57.

Adeneye, A. K., Musa, A. Z., Oyedeji, K. S., Oladele, D., Ochoga, M., Akinsinde, K. A., Z., Oyedeji, K. S., Oladele, D., Ochoga, M., Akinsinde, K. A., \& Omonigbehin, E. A. (2016). Risk factors associated with cholera outbreak in Bauchi and Gombe States in North East Nigeria. Journal of Public Health and Epidemiology, 8(11), 286-296.

Artuch-Garde, R., González-Torres, M. D. C., de la Fuente, J., Vera, M. M., FernándezCabezas, M., \& López-García, M. (2017). Relationship between resilience and selfregulation:Astudy of spanishyouthat risk of social exclusion.Frontiersinpsychology, 8 , 612.

Alkire, S., Roche, J. M., Seth, S., \& Sumner, A. (2015). Identifying the poorest people and groups: Strategies using the global multidimensional poverty index. Journal of International Development, 27(3), 362-387.

Bahadur, A. V., Ibrahim, M., \& Tanner, T. (2010). The resilience renaissance? unpacking of resilience for tackling climate change and disasters. Strengthening climate resilience institute of development studies: The University of Sussex Brighton.

Béné, C., Newsham, A., Davies, M., Ulrichs, M., \& Godfrey-Wood, R. (2014). Review article: Resilience, poverty and development. Journal of International Development, 26(5), 598-623.

Béné, C., Wood, R., Godfrey, N. A., \& Davies, M. (2012). Resilience: new utopia or new tyranny? Reflection about the potentials and limits of the concept of resilience in relation to vulnerability reduction programmes. IDS Working Papers, (405), 1-61. doi: 10.1111/j.2040-0209.2012.00405.x. 
Connor, K. M., \& Davidson, J. R. (2003). Development of a new resilience scale: The connor-davidson resilience scale (CD-RISC). Depression and anxiety, 18(2), 76-82.

Duncan, J., Tompkins, E., Dash, J., \& Tripathy, B. (2017). Resilience to hazards: Rice farmers in the Mahanadi Delta, India. Ecology and Society, 22(4). doi.org/10.5751/ ES-09559-220403.

Fan, S., Pandya-Lorch, R., \& Yosef, S. (2014). Resilience for food and nutrition security: International Food Policy Research Institute (IFPRI).

Hussaini, M. (2014b). Poverty alleviation programs in Nigeria: Issues and challenges. International Journal of Development Research,4(3), 717-720.

Idris, S., \& Kabiru, S. A. (2019). Towards promoting rural infrastructure for poverty reduction: Analysis of FADAMA III small-scale community-owned infrastructure in Kaduna and Sokoto states, Nigeria. Journal of International Studies, 15, 145-164.

Jerome, A. (2011). Infrastructure, economic growth and poverty reduction in Africa. Journal of Infrastructure Development, 3(2), 127-151.

Krantz, L. (2001). The sustainable livelihood approach to poverty reduction. Swedish International Development Cooperation Agency SIDA. Division for Policy and Socio-Economic Analysis, 1-38.

Muhammad, F. O., Nazariah, O., \& Isah, S. M. (2018). An Overview of Push/Pull factors of Political Participation in Nigeria. Journal of International Studies, 14, 81-98.

Musa, U. F., Abdullah, M.A. I. L. B., \& Wahid, R. (2016). Public policies on entrepreneurships: The implication for poverty reduction: A qualitative approach. International Journal of Management Research and Reviews, 6(10), 1393-1409.

Musa, U. F., Abdullah, M. A. I. L. B., \& Wahid, R. (2016). Politics of poverty alleviation programs in Nigeria: Challenges and prospects. Journal of Education and Social Sciences, 4(6) 311-317.

Nwabughiogu, Levinus. (2015). Nigerians living below poverty line, Vanguard, p. 2.

Olojo, A. (2013). Nigeria's troubled north: Interrogating the drivers of public support for Boko Haram. Retrieved August, 12, 2014.http://www.icct.nl/download/file/ICCTOlojo-Nigerias-Troubled-North-October-2013.pdf.

Sabiha Y, Ilyas M. K (2017). Gender difference on resilience among CVD patients. The International Journal of Indian Psychology, 4(3),70-75.

Salisu, S. S., Afandi, M. S., \& Yusuf A. S. (2015). The impact of Boko Haram insurgency on Nigerian national security. International Journal of Academic Research in Business and Social Sciences, 5(6), 254-266. doi: 10.6007/IJARBSS/v5-i6/1676.

Sanni, K. (2018). Windstorm in Bauchi state of Nigeria. https://www.premiumtimesng. com/newheadline.

Twigg, J., Calderone, M. (2019). Building livelihood and community resilience: Lessons for policy and programming from Somalia and Zimbabwe. Working paper, No. 545. 